\title{
Principles of the Military Consultations in Ancient Egypt
}

\author{
Mohsen Negmeldin* \\ Cairo University, Giza, Egypt
}

*Corresponding author: Mohsen Negmeldin, Cairo University, Giza, Egypt

\section{Introduction}

A way from the regular theory, that the royal king always had the perfect and ideal order and decision [1], when he always is depicting as an intelligent and wise man, making the correct solution against the doubts and uncertainties of his councilors [2], The pattern is basically that the king makes and demonstrates his superior judgment by the ensuing success [3].

From the beginning of the ancient Egyptian history, the royal king must had his own courtiers and advisors among the great ones $[3 \mathrm{~A}, 3 \mathrm{~B}]$, to consult with them, concerning the vital matters, especially when are relating to the country fate [4], the literary texts depicted several kinds of councils, whether were holding at the royal palace or outside it.

The first witness of holding a royal council was belonging to the 4th dynasty, at the reign of the great king Khufu, this council documented in Westcar papyrus [5] (= Berlin Papyrus 3033), when the great king Khufu summoned his sons to tell him an exciting marvel event that had happened in the past, the texts contains a cycle of tales within a single theme related to the birth of the kings who will succeed his line family rule, the episode begins when the king one day felt with a boredom, so he went around every chamber of his palace, finding something fun to entertain [6]. The story refers indirectly, the king's need to own his close and special courtiers [7], who were emerging obviously at the Middle Kingdome literary texts (Berlin leather Roll of Senusert 1) [8].

\section{Methodology}

The research is concerned with the texts which refer to the royal consultation dating since the second intermediate period (Hyksos era) till the reign of the king Thutmose III, it contains four councils, three of them were held at the $2^{\text {nd }}$ intermediate period (Apophis, Seqenenre and Kamose), while the 4th one belonged to the king Thutmose III' reign.

The research will intend to analyze those councils, the reasons of its holding, members of the council and their positions, the place of its holding, the full dialogue that happened between the king and his councilors, and however the role of both (the king and his councilors) at these councils, as well as the results and the decisions which had been adopted.

\section{Principle of Military Consultation in the Second Intermediate Period}

During the end of the $12^{\text {th }}$ dynasty of the Middle kingdom [9], considerable details are indicating an increasing in numbers and activities of the Asiatics who infiltrated and settled around the eastern borders of the Delta [10], that settlement facilitated the operation of Hyksos invasion [11], which happened in the second half of the $13^{\text {th }}$ dynasty of the Middle kingdom [12]. So, the country was divided into individual parts, the Hyksos invaders established the $15^{\text {th }}$ dynasty, that predominated the whole Delta region until the middle Egypt borders at south, while the fugitive king of the $13^{\text {th }}$ dynasty had to leave and ruled his remaining days of his reign to govern from Thebes [13], when the local governors of Thebes province hosted him and his royal family after the fall of the political capital el-Lisht, a short time passed, the Theban governors had inherited the kingship and authority and were establishing the $16^{\text {th }}$ dynasty, which began the first liberal operations against the Asiatics invaders.

This latter dynasty was followed by a strong family (the $17^{\text {th }}$ dynasty) whose kings began the true struggle and liberation wars against Hyksos, the first engagement occurred during the reign of Seqenenre Taa in the time of Ippy (Apophis) king of Hyksos.

\section{References}

1. Hermann A (1960) Die Ägyptische Königsnovelle.

2. Redford DB (2003) The Wars in Syria and Palestine of Thutmose III, CHANES 16 pp. 19.

3. Goedicke H (1986) The Quarrel of Apophis and Seqenenre, Chicago, USA, p. 1.

A. They consisted of differs of persons (princes, friends, military commanders, wise men, ....etc.)

B. The teachings for Merikare emphasis the king's need for loyal council: "Great is the great man whose great ones are great; brave is the king who possesses an entourage; a noble man is wealthy in great ones". 
4. Quack SG, Studien zur lehre fur Merikare (1992) So, we can imagine the daily regular act of the royal king is sitting down at his throne at his royal palace, especially at the (Audience Hall), surrounding by his counselors.

5. Jenni H (1998) Der Papyrus Westcar, SAK 25 pp.113-141

6. Blackman AM (1988) The story of King Kheops and the Magicians, London 1: 1-17

7. Shaw GJ (2008) Royal authority in Egypt's $18^{\text {th }}$ dynasty. BAR Inter Ser 1822: 75.

8. De Buck (1938) The Building Inscription of the Berlin Leather Roll Studia Aegyptiaca 1: 48-57.

9. Posener G (1957) Les asiatiques en Egypte sous les XIIe et XIIIe dynasties in: Syria $34: 1-2$ pp. $145-163$
10. Tallet P (2005) Sésostris III et la fin de la XIIe dynastie Paris Éd. Pygmalion pp. 160-162.

11. Bietak M (2010) From Where Came the Hyksos and Where did they go? in: The Second Intermediate Period pp. 147.

12. Ryholt KSB (1997) The Political Situation in Egypt during the Second Intermediate Period c. 1800-1500 BC, Edn. Carsten Niebuhr Institute Publications Copenhagen, Denmark 20: 86.

13. Franke D (2013) The $13^{\text {th }}$ to $17^{\text {th }}$ Dynasties: chronological framework in: Egyptian Stelae in the British Museum from the $13^{\text {th }}$ to $17^{\text {th }}$ Dynasties 1: $7-13$

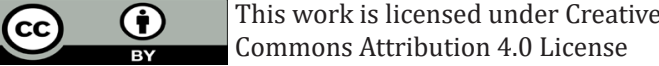

To Submit Your Article Click Here:

Submit Article

DOI: $10.32474 / J A A S .2019 .01 .000103$

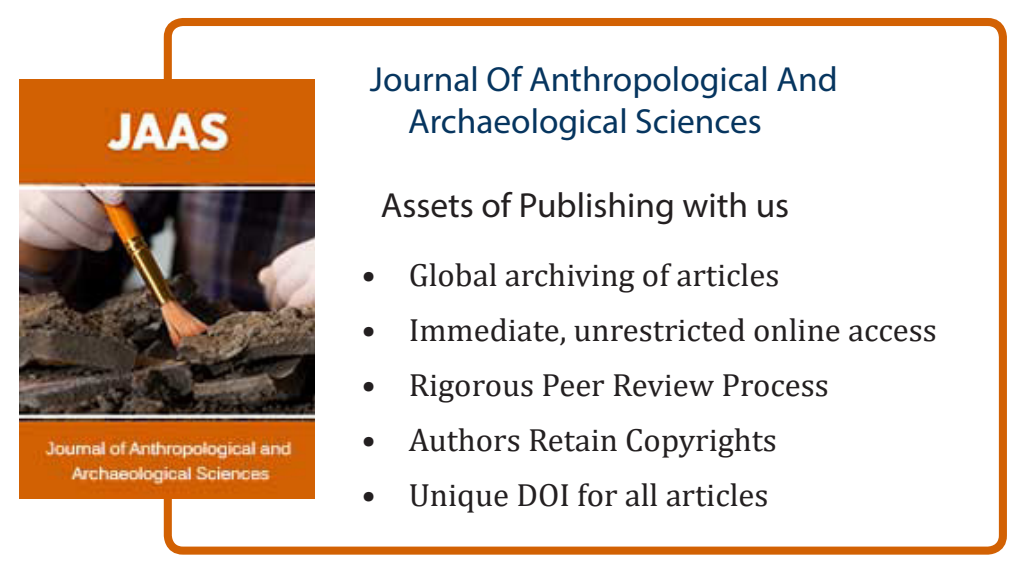

